\title{
Influence of artificial intelligence on public employment and its impact on politics: a systematic literature review ${ }^{1}$
}

\author{
João Reis ${ }^{1,2}$, Paula Espírito Santo², Nuno Melão ${ }^{3}$ \\ ${ }^{1}$ University of Aveiro, Department of Economics, Management and Industrial Engineering and Tourism, Research Unit on \\ Governance, Competitiveness and Public Policies - GOVCOPP, Aveiro, Portugal. \\ ${ }^{2}$ University of Lisbon, Institute of Social and Political Sciences - ISCSP, Centro de Administração e Políticas Públicas, Campus \\ Universitário do Alto da Ajuda, Lisbon, Portugal. \\ ${ }^{3}$ Polytechnic Institute of Viseu, Research Centre in Digital Services - CISeD, Campus Politécnico, Viseu, Portugal.
}

How to cite: Reis, J., Espírito Santo, P. and Melão, N. (2021), “Influence of artificial intelligence on public employment and its impact on politics: a systematic literature review", Brazilian Journal of Operations \& Production Management, Vol. 18, No. 3, e20211114. https://doi.org/10.14488/BJOPM.2021.010

\begin{abstract}
Goal: Public administration is constantly changing in response to new challenges, including the implementation of new technologies such as robotics and artificial intelligence (Al). This new dynamic has caught the attention of political leaders who are finding ways to restrain or regulate Al in public services, but also of scholars who are raising legitimate concerns about its impacts on public employment. In light of the above, the aim of this research is to analyze the influence of Al on public employment and the ways politics are reacting.
\end{abstract}

Design / Methodology / Approach: We have performed a systematic literature review to disclose the state-of-the-art and to find new avenues for future research.

Results: The results indicate that public services require four kinds of intelligence - mechanical, analytical, intuitive, and empathetic - albeit, with much less expression than in private services.

Limitations of the investigation: This systematic review provides a snapshot of the influence of $\mathrm{Al}$ on public employment. Thus, our research does not cover the whole body of knowledge, but it presents a holistic understanding of the phenomenon.

Practical implications: As private companies are typically more advanced in the implementation of Al technologies, the for-profit sector may provide significant contributions in the way states can leverage public services through the deployment of Al technologies.

Originality / Value: This article highlights the need for states to create the necessary conditions to legislate and regulate key technological advances, which, in our opinion, has been done, but at a very slow pace.

Keywords: Artificial Intelligence; Robotics; Policy; Employment; Public Services.

\section{INTRODUCTION}

Driven by technological advances and public interest, artificial intelligence (AI) is being considered by some to be an unprecedented revolutionary technology (Brock and Von Wangenheim, 2019). Established as an academic discipline in the 1950s, Al remained an area of relative scientific obscurity and limited practical interest for more than half a century (Haenlein and Kaplan, 2019; Wirtz and Müller, 2019). But recently, the private sector has reversed this

\footnotetext{
1 This article is from the XXVI International Conference on Industrial Engineering and Operations Management (IJCIEOM) and was invited to be published in the September/2021 Special Issue of the Brazilian Journal of Operations \& Production Management, due to its relevance and contribution to the field.
}

Financial support: None.

Conflict of interest: The authors have no conflict of interest to declare.

Corresponding author: reis.joao@ua.pt

Received: 23 Nov 2020.

Approved: 1 Dec 2020.

Editor: Luiz Felipe Scavarda.

(c) (i) This is an Open Access article distributed under the terms of the Creative Commons Attribution License, which permits unrestricted use,

(c) distribution, and reproduction in any medium, provided the original work is properly cited. 
trend, leveraging Al to another level as it has begun to integrate Al-related technologies into its service delivery systems, thereby reaching to general public (Marr, 2019; Reis et al., 2020a). This game-changing situation has shifted Al from the unique field of computer sciences to areas such as social and management sciences (Rosete et al., 2020). Furthermore, it is well known that the digital Era is not only driving innovation in the business sector, but also seems to influence developments in the public sector as well (Kokkinakos et al., 2016). Public sector digitalization is currently one of the promising topics with more prospects for future development, and yet a small percentage of academic research focuses on this domain, at least for the time being (Gauß, 2020; Reis et al., 2018; Schou and Hjelholt, 2018).

To develop scientific research in the field of study, our intention is to follow the suggestions of Reis et al. (2020b) by proposing a research based on the theory of Al job replacement of Huang and Rust (2018); similar research was developed by Rosete et al. (2020) to analyse whether service robots and Al influenced human employment, the latter focused on the private sector. Rosete et al. (2020) studied the Henn-na hotel, which fully automated its services so that guests would never find staff during their service experience. The findings suggested that, in situations of higher customer contact, service robots were unable to perform human tasks, resulting in a negative experience for guests. The point is that service robots are highly effective at performing analytical-cognitive tasks, but very limited at socialemotional ones. As for the practical implications, the Henn-na hotel had to remove more than half of its robotic workforce because robots were not capable to perform social activities. The point is that, in manufacturing many jobs have been replaced, and even if we witness an employment transition to services, the latter is not likely to be immune to job replacement either (Buera and Kaboski, 2012; Ivanov, 2020; Lu et al., 2020). Although services are known to be more difficult to be replaced, as they imply spontaneous communication interactions (Autor and Dorn, 2013) and emphatic relations (Wirtz et al., 2018), it is likely that this will soon not be the case (Huang and Rust, 2018). Therefore, from the perspective of public services, there are still many questions to answer, for instance: RQ1) Is Al significantly influencing public employment? RQ2) How is the political power expected to deal with Al-related employability issue? Contrary to the article by Rosete et al. (2020), who used the theory of Wirtz et al. (2018), because it focuses specifically on front-line service robots, we used the theory of Huang and Rust (2018). This theory specifies four types of intelligence required for service tasks mechanical, analytical, intuitive, and empathetic - and is, therefore, better suited to our paper as it is broader and focused on Al in general services. Later on, Huang et al. (2019) merged the analytical and intuitive intelligence into thinking intelligence. To have a more detailed analysis, we will apply the original four types of artificial intelligence (Huang and Rust, 2018).

Last but not least, a statement of public employment and political power must be briefly discussed to properly address the research questions in the next sections. In that regard, we witness that the definition of public employment differs due country-specific regulations and reforms trajectories of public employment regimes and therefore it has not reached universal consensus (Gimpelson and Treisman, 2002, Behar and Mok, 2013). Although imprecise, the definition by Gottschall et al. (2015) seems complete, in that they define the term public employment as a large and heterogeneous group of employees who are directly or indirectly involved in the production and supply of publicly-financed goods and services; other definitions tend to exclude companies owned by the state for operating in the private sphere. Before moving on to the definition of "political power", it is relevant to note that "power" has long been "one of the key concepts in the great Western tradition of thought about political phenomena" (Parsons, 1963, p. 232). Although, it has already been much discussed in the field of political science, it seems that there is also no consensus on its definition. Some recent definitions have a rhetoric keen to coercion, vide Holcombe (2020, p. 4), which defines political power as "the ability to use the institutional framework to credibly threaten to impose costs on people so they will act as those with political power want them to act". As mentioned by Haugaard (2020, p. 1), Carl Schmitt and Rousseau also saw politics as having a sacred element, whereby the leader's pronouncements are analogous to the voice of a God; however, for most liberal and plural-oriented Democrats, this form of charismatic authority represents a threat to the democratic system (Haugaard, 2020, p. 1). If we take into account a more neutral perspective, while remaining modernist, the definition of political power focuses on the contrast between power in terms of agency/State and the way in which social conscience creates conditions for possible for action (Journal of Political Power, 2020). 
We have structured this paper into five sections. After the introduction, the subsequent section provides an overview of the topic and discusses the most relevant concepts. This is followed by an explanation of the methodological process. The results of the systematic literature review are also discussed, while the objective is to present conceptual evidence about the influence of Al on public employment and its impact on public policy. Finally, we explore the contributions to theory and practice, as well as suggestions for future research.

\section{CONCEPTUAL BACKGROUND}

The Al concept has been defined from different perspectives, so we venture to say that it has triggered the attention of researchers at a multidisciplinary level. In general terms, Al is being coined in the literature as a human behaviour that can be performed by machines, systems or networks (Li and Du, 2017). According to Russell and Norvig (2016), Al may comprise thought processes and reasoning, but also a human behavioural component. That is, the definition must, on the one hand, present a more human-centred approach that should include empirical sciences covering human behaviour notions, and, on the other hand, focus on a combination of mathematical and engineering models. Moreover, some authors argue that Al has gone through three distinct research phases (Darlingtom, 2017; Sharma et al., 2020): the first reflects developments on computing capacity and processing power; the second focus on the development of artificial neural networks, which mainly tries to simulate the human brain; the third wave has been driven by deep learning and real-world applications. Knowing the intentions of Al to mimic the human brain, Turing (1950) tried early to make a distinction between "computing machinery" and "intelligence". The concept of intelligence has continuously evolved and it is generally viewed as the ability to learn from experience, as well as to adapt to the surrounding environment (Sternberg, 1996). In light with the above, Huang and Rust (2018) have also provided some inputs, and presented four different types of intelligence - mechanical, analytical, intuitive, and empathetic - ordered by degree of complexity. The Al job theory asserted that job ${ }^{2}$ replacement should occur first at task level, rather than job level due the degree of complexity (i.e. easier tasks can be most easily performed by Al-enabled technologies rather than most complex ones - e.g. intuitive and empathetic). In a seemingly far-fetched context of our reality, Al will also be capable of performing intuitive and empathetic tasks (Huang and Rust, 2020; Rosete et al., 2020).

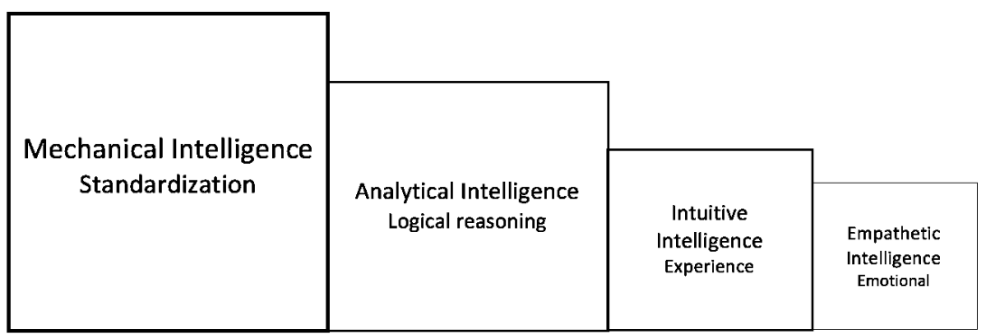

Figure 1. The four types of Al intelligences. Source: Adapted from Huang and Rust (2018).

Thorndike (1920) has divided intelligence in three dimensions: 1) abstract intelligence, which is the ability to manage, understand ideas and symbols (Newsome et al., 2000); 2) mechanism intelligence, that is, the "ability to learn, to understand and manage things and mechanisms" (Thorndike, 1920, p. 228); 3) social intelligence, known as the ability to manage and lead with people (Kihlstrom and Cantor, 2000). Thus, the first level of intelligence in Figure 1 is the mechanical intelligence, which is the ability to manage repetitive tasks.

Sternberg (1996) also divided intelligence in a triadic dimension: 1) analytical intelligence that analyses, compares and evaluates information for problem solving; 2) practical intelligence gained particular relevance in allowing generalization of knowledge from a

\footnotetext{
${ }^{2} \mathrm{~A}$ job comprises a set of tasks that an employee performs and tasks are defined as activities involved in an occupation, therefore a job usually includes several tasks (Huang and Rust, 2018)
} 
particular context to other contexts; 3) creative intelligence, which is relevant to novel situations that require skills that may be only loosely on past experiences (Tigner and Tigner, 2000). The second level of intelligence is the analytical intelligence which is the ability to process information to solve problems.

Intuitive intelligence is considered as the ability to analyse alternatives with deeper insight, transcending simple rational thinking (Jarrahi, 2018). This is the third level of intelligence, which requires creative thinking and the capacity to adjust to novel situations (Huang and Rust, 2018).

Concerning the fourth intelligence, emotional intelligence involves recognizing emotions and processing emotional information as part of the overall problem-solving ability (Mayer and Geher, 1996). Other authors have used different terminology than empathetic intelligence (Huang and Rust, 2018). We have used emotional intelligence since it serves as a foundation for empathy (Beauvais et al., 2017). To better understand the aforementioned concepts, we provide an example below (Table 1).

Table 1. Types of intelligences and tasks from banking services

\begin{tabular}{ccccc}
\hline $\begin{array}{c}\text { Types of } \\
\text { Intelligences }\end{array}$ & $\begin{array}{c}\text { Mechanical } \\
\text { intelligence }\end{array}$ & $\begin{array}{c}\text { Analytical } \\
\text { intelligence }\end{array}$ & $\begin{array}{c}\text { Intuitive } \\
\text { intelligence }\end{array}$ & $\begin{array}{c}\text { Empathetic } \\
\text { intelligence }\end{array}$ \\
\hline Banking agency & $\begin{array}{c}\text { Standardized } \\
\text { replies }\end{array}$ & $\begin{array}{c}\text { Logical } \\
\text { reasoning }\end{array}$ & $\begin{array}{c}\text { Experience-based } \\
\text { understanding }\end{array}$ & $\begin{array}{c}\text { Social-emotional } \\
\text { relations }\end{array}$ \\
\hline
\end{tabular}

Source: Based on Duffy et al. (2006), Shapiro and Nieman-Gonder (2006), Reis et al. (2019a; 2019b; 2020c).

Consider a frontline employee from a banking agency that replies to a customer complaint by following standardized scripts (Reis et al., 2020c). In practical terms, this type of complaint leads to immediate and standardized answers due to the high level of repeatability (Reis et al., 2019a) - given the nature of the task (mechanical intelligence), the recovery process can be easily replaced by Al. A subsequent phase (analytical intelligence) is represented by a frontline employee that analyses a customer complaint by posting some direct questions to screen and identify an issue. From the aforementioned situation, logical reasoning is required to make a proper decision. In some other cases (intuitive intelligence), the bank employee has to use his/her intuition, experience and contextual interactions to understand the complaint and seek a reasonable answer (Reis et al., 2019b). A more complex situation (empathetic intelligence) is when the bank employee has to show empathy by listening to the complaint, apologizing and calm the customer down (Duffy et al., 2006; Shapiro and Nieman-Gonder, 2006). This last interaction requires social-emotional relationships, which is harder to be replaced by Al. Yet, Al has already substituted human employment in areas that were previously thought to be uncomputerizable (Bruun and Duka, 2018).

In addition to what was previously mentioned, recent developments in robots and Al also herald an unprecedented political, economic and social transformation. In that regard, Boyd and Holton (2018) argue that in the public debate the rhetorical moment in business and policymaking is behind the technological determinists. The relevance of Al in the politicaleconomic-social landscape is well-evidenced in many crises. An example is the recent dispute between the United States of America and China, which resulted in the United States Department of Defence's restrictions on the use of Huawei technologies (Ernst, 2020; Kaplan and Haenlein, 2020; Kapustina et al., 2020) and which has suffered a series of deadlocks. Therefore, those in the race for Al development are likely to dominate the coming decades, especially in terms of economic and geopolitical strength, which will potentially exacerbate tensions between countries (Feijóo et al., 2020). The Al holistic outlook may be summarized to the following countries (Kaplan and Haenlein, 2020): 1) China is using Al improve its economic position worldwide (Brown, 2020); 2) in the USA, Al is being driven by a number of technology companies that ultimately aim to profit (Eliasy and Przychodzen, 2020); 3) in the $\mathrm{EU}$, the focus is on data protection and the privacy of its citizens, as evidenced by the 
establishment of the General Data Protection Rule (Allen and Masters, 2020; Bessen et al., 2020; Mercer, 2020), as well as the political stability (Mosteanu, 2020). Thus, according to Kaplan and Haenlein (2020) the underlying challenge is to coordinate these contradictory goals. In addition to the effect of Al on foreign and domestic policy, Al also raises concerns about job replacement or process dehumanization, exacerbating social e economic divisions (West, 2015). Also in that regard, the biggest challenge is unlikely to be the identification of the existing Al dangers, but rather the response of public governance (Dignam, 2020).

\section{METHODOLOGY}

This paper follows a qualitative methodology, which analyses the content of retrieved sources from Scopus, one of the world's largest abstract and citation databases of peerreviewed research literature. The chosen method for this paper was a systematic literature review, in order to provide an objective and comprehensive summary of the existing literature (Blaxter, 2010; Petticrew and Roberts, 2008). The use of this method is also justified by the recent studies that reinforce the argument that $\mathrm{Al}$ research and the technological developments in the public sector, their applications and the results of using these strategies is still scarce and need to be systematized (Sousa et al., 2019). Thus, we present the current state-of-the-art and, at the same time, focus the discussion on the research questions already presented in the introduction. Moreover, following the assumptions of Tranfield et al. (2003), we used a clear set of steps to be replicated, and only one database to enhance transparency. Scopus was chosen from several relevant databases, such as Web of Science (WoS) or EBSCO Host, because, as justified by Reis et al. (2019c, 2020d), has a wider coverage of articles, indexing a broader range of $\mathrm{Al}$ journals. With regard to academic search engines, such as Google Scholar, they were excluded because our priority was to select only articles evaluated by peers for reasons of quality and credibility. As such, a Scopus search was conducted on January $3^{\text {rd }}, 2020$, and started with the inclusion criteria by using the keywords "artificial intelligence" and "employment" in title-abstract-keywords.

Table 2. Literature review process

\begin{tabular}{ccc}
\hline & \multicolumn{2}{c}{ Scopus - Elsevier } \\
\hline Selected keywords & “Artificial Intelligence” AND Employment \\
\hline Search & title-abs-key & 783 \\
\hline Language & English & 764 \\
\hline Source type & Journals & 255 \\
\hline Document type & Articles & 229 \\
\hline Subject area & Social Sciences, Management, \\
& Engineering & 128 \\
\hline
\end{tabular}

Source: The authors.

Although $\mathrm{Al}$ job replacement is considered in the academic field as a central topic (Makridakis, 2017; Frank et al., 2019), we found that Scopus did not generate a wide range of research streams, reinforcing the need for studies in this field. To get more accurate results we applied a series of filters, namely: language, source type, document type and subject area (Table 2). Accordingly, the search included articles published in English due to linguistic limitations. The second and third step of the process included journal articles from the perspective of only considering higher quality publications; hence, we have not considered conference proceedings, book chapters, etc. Finally, we focused on areas such as the social and management sciences - mostly to seek the political and public administrators' perspectives; and engineering - to gain a technical understanding of Al technologies and robotics. Following some of the usual exclusion criteria (i.e. lack of full paper access and articles out of context), it resulted that all the articles were included in the study. Therefore, the final sample included 128 peer-reviewed journal articles (see Appendix A).

The data analysis followed the content analysis technique (Neuendorf, 2016; Krippendorff, 2018), which began by reading all the 128 selected articles, in order to familiarize 
with new concepts and the most relevant ideas. In a second stage, we coded similar words and terms. By grouping the text, it was possible to identify categories and subcategories (Cenamor et al., 2017). The third stage aimed to hierarchize the categories and subcategories to identify new patters and ideas (Given, 2008; Hancock and Algozzine, 2016). The last stage aimed to refine the generated themes and provide a holistic view. The final result can be found in Table 3. As an example, from this table we are able to understand that several excerpts taken from the literature (codes) were grouped in categories under the topic of public transports, these led us to identify a series of associated technologies that are a part of these systems, and the consequences for public employment. A number of proposals and measures to be taken by government agencies were also identified. Moreover, Table 3 cites the examples of selected articles that refer to the topic under study. To assist in the above process, we used qualitative data analysis software, known as NVivo QSR International, Version 11, that allowed to code a large volume of data and to easily identify emerging patterns and ideas (Woolf and Silver, 2017; NVivo, 2020).

Our article is not free of limitations. Since Scopus database is constantly being updated, it is likely that some articles will be left out. In addition, this systematic review provides a snapshot of a given reality, at a particular moment of time. Our research does not cover the whole body of knowledge, largely due to the limited number of keywords. For instance, we could focus on a particular Al technology, such as machine learning, however our goal was to present a holistic and less restricted understanding of the phenomenon. On the other hand, the keyword "employment" is not restrictive either, as it may include private and public employment, although the focus was on the latter. Acknowledging these limitations, we consider that this systematic review will bring added value to the literature, in the extant that it contributes to increase the Al body of knowledge to a specific and quite unexploited area.

\section{FINDINGS}

This section summarizes the main findings of the systematic review and presents a discussion on the topic. Our main intention is to provide an overview of the state-of-the-art, answers to the research questions, and to stimulate future research about Al and its influence on public employment. Before starting to discuss the results, which emerged from the content analysis, it is relevant to show some of the general results from Scopus.

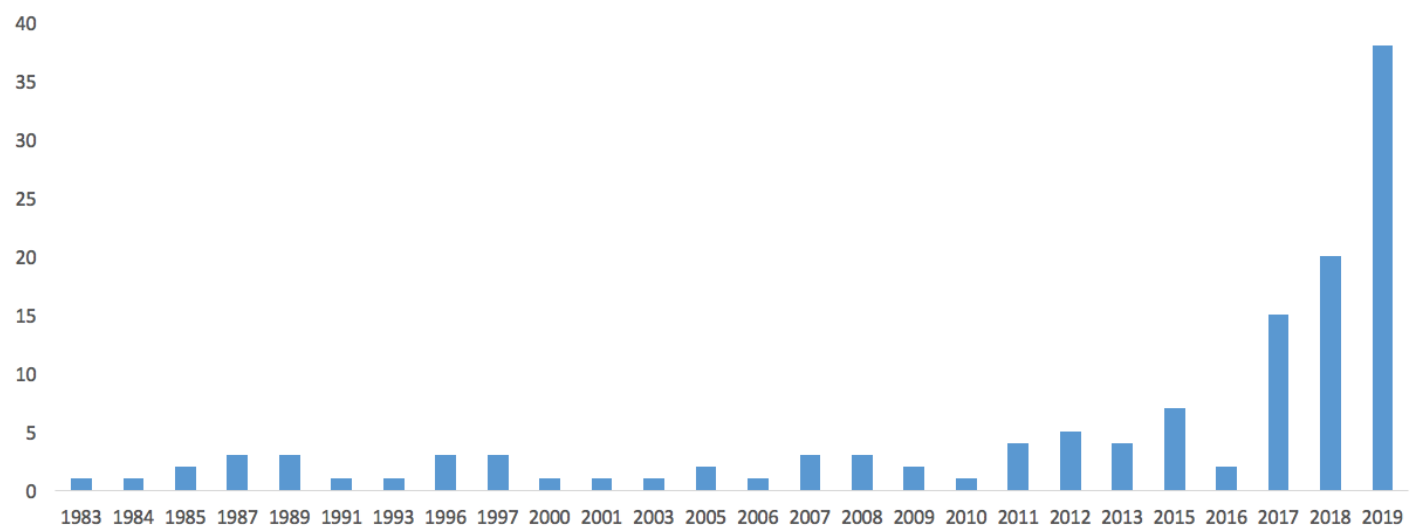

Figure 2. Published documents by year. Source: Retrieved from Scopus.

In recent years, we have witnessed an exponential increase in $\mathrm{Al}$ research on employment (Figure 2). In 2019, we found 38 publications, many of which focused on the division of human labour and machines (Hammershøj, 2019); the latter included robotics enhanced by Al-related technologies. Overall, we could find different points of view: - first, some authors are rethinking the effects of machines on future work relations with humans (Lloyd and Payne, 2019); - second, the impact of emotional intelligence is still gaining relevance as it limits the $\mathrm{Al} \mathrm{job}$ replacement (Kaplan and Haenlein, 2020). A particular attention is also being paid to the impact of machines on industry 4.0 (Marengo, 2019; Tien, 2020) but 
not in services at all; an exception is Li et al. (2019), which evaluated hotel employee's Al and robotics awareness and its impact on turnover intentions.

One of the possible causes that triggered the largest number of articles in the United States (Figure 3 ) is the phenomenon of having more workers performing routine tasks in similar occupations than in Germany and which have resulted in greater risk of job loss (Arntz et al., 2016). This aspect is in line with the literature that gives rise to a great consensus on the most susceptible types of jobs and workers that are expected to be replaced by Al, and which are mainly "routine" and "low qualified" activities (Hall et al., 2019; Lloyd and Payne, 2019). According to the above, many attempts have been made to measure the impact of robots and Al on employment; one of the most cited research in this context is the article by Frey and Osborne (2017), which is based on a group of "experts" who assess whether individual occupations can be replaced by a robot or Al. The authors concluded that nearly $47 \%$ occupations in the United States are at risk of automation in the next two decades. The worst case scenario is accompanied by advances in Al and machine learning, which may be ready to take on not only the routine or repetitive tasks, but also some of the more complex and empathetic tasks (Estlund, 2018).

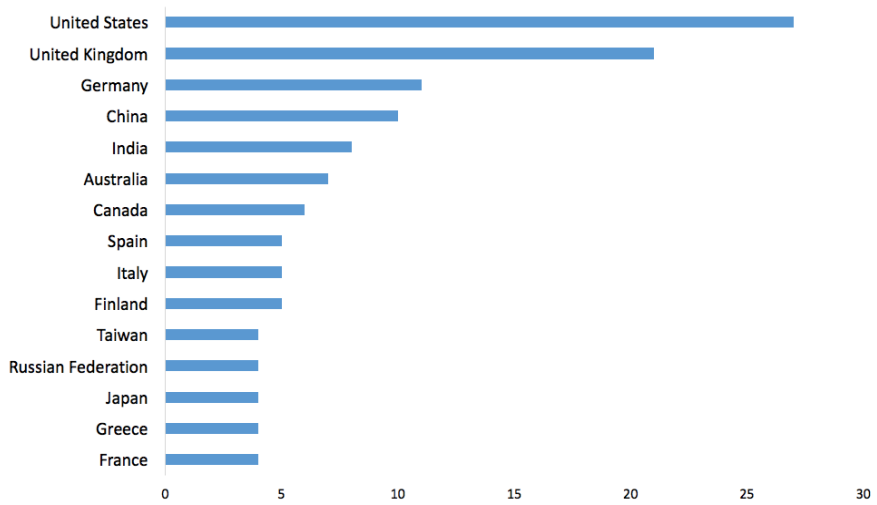

Figure 3. Analyse search results by country. Source: Retrieved from Scopus.

The reality in the United Kingdom is not different from the United States, unlike Germany, which has a long history of using new technologies in the industry, particularly in the context of industry 4.0 (Budanov et al., 2017; Nam, 2019). Germany's main strategy has been to support the country's export champions and drive smart services based on machine learning technologies (Lauterbach, 2019). Therefore, one of the aspects is the migration of emerging technologies to services, which is still dominated by human employment.

Frey and Osborne (2017) make two key observations. First, they argue that jobs involving human interaction, such as political and managerial occupations, will remain under human control, which justifies the fact that current research are predominantly under the social sciences domain (Figure 4); Second, highly specialized/technical and scientific competencies will be enhanced by humans with skills to keep machines operational, justifying the research developments in areas such as engineering and computer science.

Concerning RQ1, we have noticed that the various levels of intelligence for service tasks can be replaced by AI in the sphere of public employment (Table 3). Our analysis revealed that mechanical intelligence will tend to be more prone to be replaced by machines than in empathetic intelligence. In the latter case, we found that technologies are assisting decisionmaking and interaction with humans for choosing political parties based on gathering citizens' feelings and voting intentions; but these technologies are still a long way from being able to replace politicians, contrary to what European citizens would like (Kaplan and Haenlein, 2020). Unlike empathetic activities, mechanical tasks such as public transports or financial services will tend to become more autonomous due Al developments; however, in these cases we found some restrictions, such as obstacles to use certain Al technologies due to road safety measures (Estlund, 2018), as well as safeguarding citizens' freedoms and rights 
(Lauterbach, 2019). We have generally found that governments can decide whether to retain human labour or force companies to reduce or restrict the use of automation. In France, for example, there are already laws that require electronic platforms to be usable only during business hours (Kaplan and Haenlein, 2020).

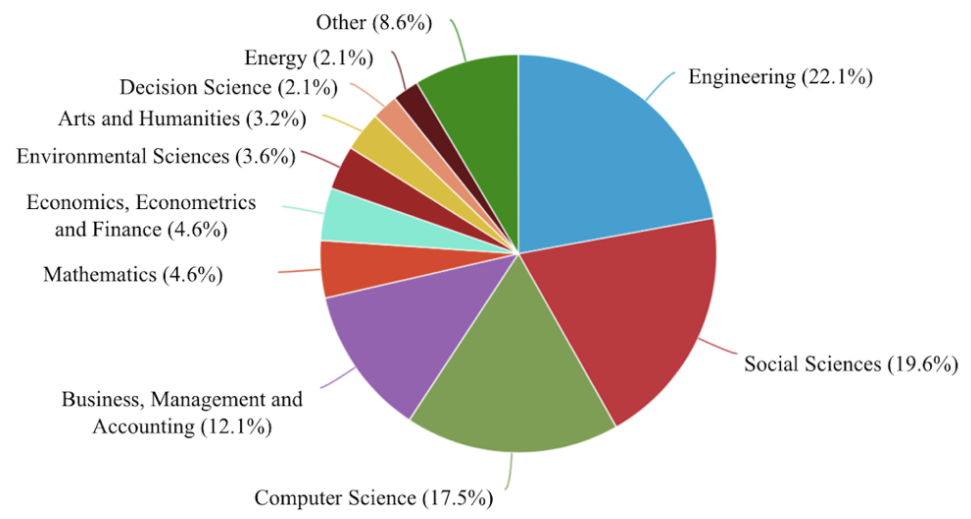

Figure 4. Results divided by subject area. Source: Retrieved from Scopus.

In some cases, we could not find a consensus in the literature. For example, the biggest threat to jobs has been seen in sectors such as public finances. In that regard, Lloyd and Payne (2019) showed that no significant job cuts have been found so far, suggesting an overestimation of academic projections. On the other hand, authors like Sachs (2019) argue that online tax payment systems will tend to replace frontline employees. In short, we have identified some gaps in the literature with regard to public services since the advancements, so far, have been mainly made in the private sector.

Table 3. Influence of artificial intelligence on public employment and its impacts on politics

\begin{tabular}{|c|c|c|c|c|}
\hline \multicolumn{2}{|c|}{ Type of Intelligence } & \multicolumn{2}{|c|}{ Cases of Public Job Replacement } & \multirow{2}{*}{$\begin{array}{c}\text { Political outlook } \\
\text { Relevance }\end{array}$} \\
\hline Al & Labour & Al technology & Literature & \\
\hline \multicolumn{5}{|c|}{ Mechanical | Routine, Standardized and Repetitive tasks } \\
\hline - Service & • Job type & - Type of technology & - Author(s) & - Expected measures \\
\hline $\begin{array}{l}\text { Public } \\
\text { transports }\end{array}$ & Drivers & $\begin{array}{c}\text { Autonomous vehicles, } \\
\text { and automated public } \\
\text { transport }\end{array}$ & $\begin{array}{l}\text { Estlund (2018); } \\
\text { Walsh (2018); } \\
\text { Sachs (2019) }\end{array}$ & $\begin{array}{l}\text { Restrain: Concerns about } \\
\text { traffic safety may slow } \\
\text { down the advent of } \\
\text { autonomous vehicles } \\
\text { (Estlund, 2018) }\end{array}$ \\
\hline $\begin{array}{c}\text { Table } 3 . \text { Cont } \\
\text { Financial } \\
\text { services }\end{array}$ & $\begin{array}{l}\text { ued... } \\
\text { Frontline } \\
\text { employees }\end{array}$ & $\begin{array}{l}\text { Low-cost e-payment } \\
\text { systems; online tax and } \\
\text { transfer payments; e- } \\
\text { finance }\end{array}$ & $\begin{array}{l}\text { Lloyd and } \\
\text { Payne (2019); } \\
\text { Sachs (2019) }\end{array}$ & $\begin{array}{c}\text { Enforce: Transparency } \\
\text { concerns, citizens' rights } \\
\text { and liberties may block } \\
\text { some of the Al-enhanced } \\
\text { technologies (Lauterbach, } \\
\text { 2019) }\end{array}$ \\
\hline \multicolumn{5}{|c|}{ Analytical | Systematic and Logical Thinking } \\
\hline - Service & • Job type & - Type of technology & - Author(s) & - Expected measures \\
\hline Defence & $\begin{array}{l}\text { Military; } \\
\text { Intelligence } \\
\text { analysts }\end{array}$ & $\begin{array}{l}\text { Al in military and } \\
\text { defence - Google } \\
\text { Project Maven used Al } \\
\text { technologies in the } \\
\text { battlefield to improve } \\
\text { targeting and }\end{array}$ & $\begin{array}{l}\text { Lauterbach } \\
\text { (2019) }\end{array}$ & $\begin{array}{l}\text { Regulate: Ethical and legal } \\
\text { issues are at stake when } \\
\text { using Al lethal weapon } \\
\text { systems. There has been } \\
\text { social pressure to block the } \\
\text { developments of such } \\
\text { innovations. }\end{array}$ \\
\hline
\end{tabular}




\begin{tabular}{|c|c|c|c|c|}
\hline \multicolumn{2}{|c|}{ Type of Intelligence } & \multicolumn{2}{|c|}{ Cases of Public Job Replacement } & \multirow{2}{*}{$\begin{array}{c}\text { Political outlook } \\
\text { Relevance }\end{array}$} \\
\hline Al & Labour & Al technology & Literature & \\
\hline & & $\begin{array}{l}\text { surveillance } \\
\text { capabilities. }\end{array}$ & & \\
\hline \multicolumn{5}{|c|}{ Intuitive | Contextual and Experience-based Interactions } \\
\hline - Service & - Job type & - Type of technology & • Author(s) & - Expected measures \\
\hline $\begin{array}{l}\text { Healthcare } \\
\text { services }\end{array}$ & $\begin{array}{l}\text { Nursing, } \\
\text { Doctors }\end{array}$ & $\begin{array}{l}\text { Remote monitoring of } \\
\text { patients; remote } \\
\text { diagnostics; expert } \\
\text { automated health } \\
\text { systems }\end{array}$ & $\begin{array}{c}\text { Lloyd and } \\
\text { Payne (2019); } \\
\text { Sachs (2019) }\end{array}$ & $\begin{array}{c}\text { Enforce: Transparency } \\
\text { concerns, citizens' rights } \\
\text { and liberties may block } \\
\text { some of the Al-enhanced } \\
\text { technologies (Lauterbach, } \\
\text { 2019) }\end{array}$ \\
\hline \multicolumn{5}{|c|}{ Empathetic | Social and Emotional Interactions } \\
\hline - Service & - Job type & - Type of technology & • Author(s) & - Expected measures \\
\hline Governance & Politicians & $\begin{array}{l}\text { Current technology did } \\
\text { not reach the desirable } \\
\text { state to replace political } \\
\text { activities; however, } \\
\text { tools such as RoboVote } \\
\text { are currently aiding } \\
\text { citizens to identify the } \\
\text { best party to vote for } \\
\text { given their political } \\
\text { preferences. } \\
\text { In the future, policy- } \\
\text { related technologies } \\
\text { may have greater } \\
\text { interaction with citizens } \\
\text { such as the } \\
\text { development of } \\
\text { chatbots and virtual } \\
\text { voice assistance. }\end{array}$ & $\begin{array}{l}\text { Kaplan and } \\
\text { Haenlein } \\
(2020)\end{array}$ & $\begin{array}{l}\text { Recent surveys suggest } \\
\text { that } 25 \% \text { of Europeans } \\
\text { would prefer if policy } \\
\text { decisions were made by Al } \\
\text { instead of politicians, who } \\
\text { may turn out to be corrupt } \\
\text { or ideologically extreme } \\
\text { (Kaplan and Haenlein, } \\
2020 \text { - we did not identify } \\
\text { any measure from politics } \\
\text { related to this topic - more } \\
\text { research is needed in this } \\
\text { regard. }\end{array}$ \\
\hline
\end{tabular}

Source: Adapted from Huang and Rust (2018)

Regarding RQ2, not surprisingly, there is a lack of studies which could provide credible insights with regard to unemployment caused by technological developments. One exception is Nilsson (1985), which reinforces our previous findings. The author presented several ways to deal with the unemployment issue: first, an attempt can be made to slow down the technological advancements by placing obstacles to delay or prevent unemployment, this technique is also known as "Luddite approach", which will ultimately tend to fail since no government or pressure group has the power to prevent technological progress; a second solution is to create jobs that are either unnecessary or can be easily performed by machines, the underlying objective is to distribute income, but it is unfair to those that really contribute to the economy; a third solution is to follow Kelso and Adler (1958) proposal, who imagined a society in which machines do all the work, or at least most part of it, to provide the wealth necessary for subsistence and for civilization. Therefore, the objective is to allow people to devote more time into value added activities, rather than the mechanical ones. In a modernday configuration with respect to employability issues, politicians must: 1) demystify the public unemployment due to new technologies; let's look at the case of Uber that created thousands of jobs, although it is expected that in the short term, they will be replaced by autonomous vehicles. Therefore, the question that arises at this level is not whether Al will create unemployment, but whether states will be able to adapt to the short cycles of technological innovation; 2) in addition, states should invest in the creation of specialized employment in activities to support the implementation and management of new technologies and to 
strengthen human employment in frontline activities, the latter in greater contact with citizens and where it is needed greater empathetic intelligence; 3 ) finally, the mechanical activities without added value and which have been increasing the bureaucracy of the state can eventually be migrated to the private sector that has greater know-how in managing big data.

One of the main results of this research is the need for further discussion on the topic and, on the other hand, filling a gap in the literature, since no article to date has mapped the services of a State, in order to identify which areas of government action are being automated. Without a radiograph of the current processes of State services, it is difficult to understand the citizen behaviour and which different areas of government are being automated. Only then, it will be possible to understand the relationship between the implementation of $\mathrm{Al}$ technologies and the resulting unemployment rate in public services. As soon as a study of this nature is carried out, it will be possible to clearly understand the necessary measures to be taken by the States and, consequently, to objectively answer the RQ2.

\section{CONCLUSION}

Although we acknowledge that empirical data is necessary to reinforce our findings, we believe this research somewhat corroborates Huang and Rust's (2018) four types of intelligence for public services. From the point of view of employability, the question that arises is about the capacity of states to adapt to the technological short innovation cycles. We found some evidences that politicians are restraining or trying to regulate Al applications in public services. Despite the arguments that may eventually be used, it does not seem a good idea to politically slow down the technological innovation. What seems more logical and reasonable is to create the necessary conditions to legislate and regulate the most advanced technologies, which in our opinion has been done so far, but at very slow pace. On the other hand, regulating does not mean to add barriers to the use of Al technologies as has happened with the use of autonomous vehicles in some countries, it means allowing the use of these means in a more responsible way.

As private companies are significantly more advanced in the development of $\mathrm{Al}$ technologies, the aforementioned sector may provide significant contributions. The perspective is that future research may eventually focus on outsourcing state services, at least to some degree, by replacing mechanical tasks by machines. On the other hand, politicians should be concerned to create opportunities that bring added value to the political activity or at least to keep public jobs that require empathetic and social skills on human hands. In the current state-of-the-art, it is more appropriate to retain and retrain the existing human workforce, maintaining the personalization of the public services rather than thinking about the possibility to automate tasks which require intuitive or even empathetic skills.

\section{REFERENCES}

Allen, R. and Masters, D. (2020), "Artificial Intelligence: the right to protection from discrimination caused by algorithms, machine learning and automated decision-making", ERA Forum, Vol. 20, No. 4, pp. 585598. https://doi.org/10.1007/s12027-019-00582-w.

Arntz, M., Gregory, T. and Zierahn, U. (2016), "The risk of automation for jobs in OECD countries: a comparative analysis", OECD Social, Employment, and Migration Working Papers, No. 189, pp. 1-35. https://dx.doi.org/10.1787/5jlz9h56dvq7-em.

Autor, D. and Dorn, D. (2013), "The growth of low-skill service job and the polarization of the US labor market", The American Economic Review, Vol. 103, No. 5, pp. 1553-97. http://dx.doi.org/10.1257/aer.103.5.1553.

Beauvais, A., Andreychik, M. and Henkel, L. (2017), "The role of emotional intelligence and empathy in compassionate nursing care", Mindfulness \& Compassion, Vol. 2, No. 2, pp. 92-100.

Behar, M. and Mok, M. (2013), “Does public-sector employment fully crowd out private-sector employment?", International Monetary Fund, available https://www.imf.org/external/pubs/ft/wp/2013/wp13146.pdf (accessed 8 September 2020). 
Bessen, J., Impink, S., Reichensperger, L. and Seamans, R. (2020), “GDPR and the importance of data to Al startups", NYU Stern School of Business. http://dx.doi.org/10.2139/ssrn.3576714.

Blaxter, L. (2010), How to Research, McGraw-Hill Education, United Kingdom.

Boyd, R. and Holton, R. (2018), "Technology, innovation, employment and power: Does robotics and artificial intelligence really mean social transformation", Journal of Sociology, Vol. 54, No. 3, pp. 331 45.

Brock, J.K.-U. and Von Wangenheim, F. (2019), "Demystifying Al: what digital transformation leaders can teach you about realistic artificial intelligence", California Management Review, Vol. 61, No. 4, pp. 11034. https://doi.org/10.1177/1536504219865226.

Brown, J. (2020), "An exploration of the nascent ai race dynamics between the United States and China", MUNDI, Vol. 1 No. 1, pp. 1-40.

Bruun, E. and Duka, A. (2018), "Artificial intelligence, jobs and the future of work: racing with the machines", Basic Income Studies, Vol. 13, No. 2. http://dx.doi.org/10.1515/bis-2018-0018.

Budanov, V., Aseeva, I. and Zvonova, E. (2017), "Industry 4.0.: socio-economic junctures”, Economic AnnalsXXI, Vol. 168, No. 11-12, pp. 33-37. https://doi.org/10.21003/ea.V168-07.

Buera, F. and Kaboski, J. (2012), "The rise of the service economy", The American Economic Review, Vol. 102, No. 6, pp. 2540-69.

Cenamor, J., Sjödin, D. and Parida, V. (2017), "Adopting a platform approach in servitization: Leveraging the value of digitalization", International Journal of Production Economics, Vol. 192, pp. 54-65.

Darlingtom, K. (2017), "The emergence of the age of $\mathrm{Al}^{\prime}$, OpenMind, available at: https://www.bbvaopenmind.com/en/technology/artificial-intelligence/the-emergence-of-the-ageof-ai/ (accessed 7 January 2020).

Dignam, A. (2020), "Artificial intelligence, tech corporate governance and the public interest regulatory response", Cambridge Journal of Regions, Economy and Society, Vol. 13, No. 1, pp. 37-54.

Duffy, J., Miller, J. and Bexley, J. (2006), "Banking customers' varied reactions to service recovery strategies", International Journal of Bank Marketing, Vol. 24, No. 2, pp. 112-32.

Eliasy, A. and Przychodzen, J. (2020), "The role of Al in capital structure to enhance corporate funding strategies", Array, Vol. 6, 100017.

Ernst, D. (2020), Competing in Artificial Intelligence Chips: China's Challenge amid Technology War, Centre for International Governance Innovation, Special Report, available at: https://ssrn.com/abstract=3564669 (accessed 24 May 2020).

Estlund, C. (2018), "What should we do after work? Automation and employment Law", The Yale Law Journal, Vol. 128, No. 2, pp. 254-326. http://dx.doi.org/10.2139/ssrn.3007972.

Feijóo, C., Kwon, Y., Bauer, J. et al. (2020), "Harnessing artificial intelligence (Al) to increase wellbeing for all: the case for a new technology diplomacy", Telecommunications Policy, Vol. 44, No. 6, 101988. http://dx.doi.org/10.1016/j.telpol.2020.101988.

Frank, M., Autor, D., Bessen, J. et al. (2019), "Toward understanding the impact of artificial intelligence on labor", Proceedings of the National Academy of Sciences of the United States of America, Vol. 116, No. 14, pp. 6531-9. http://dx.doi.org/10.1073/pnas.1900949116.

Frey, C. and Osborne, M. (2017), "The future of employment: how susceptible are jobs to computerisation", Technological Forecasting and Social Change, Vol. 114, pp. 254-80. http://dx.doi.org/10.1016/j.techfore.2016.08.019.

Gauß, V. (2020), "The challenges of digitalization for the (German) State", in Feldner, D. (Ed.), Redesigning Organizations, Springer, Cham, pp. 207-214. http://dx.doi.org/10.1007/978-3-030-27957-8_15.

Gimpelson, V. and Treisman, D. (2002), "Fiscal games and public employment: a theory with evidence from Russia", World Politics, Vol. 54, No. 2, pp. 145-83. http://dx.doi.org/10.1353/wp.2002.0003.

Given, L. (2008), The SAGE Encyclopedia of Qualitative Research Methods, Sage Publications, Los Angeles.

Gottschall, K., Kittel, B., Briken, K. et al. (2015), "Public employment regimes in OECD countries", in Gottschall, K., Kittel, B., Briken, K. et al. (Eds.), Public Sector Employment Regimes, Palgrave Macmillan, London, pp. 69-106. 
Haenlein, M. and Kaplan, A. (2019), "A brief history of artificial intelligence: on the past, present, and future of artificial intelligence", California Management Review, Vol. 61, No. 4, pp. 5-14. http://dx.doi.org/10.1177/0008125619864925.

Hall, R., Ashford, R., Ashford, N. et al. (2019), "Universal Basic Income and Inclusive Capitalism: consequences for Sustainability", Sustainability, Vol. 11, No. 16, pp. 4481 http://dx.doi.org/10.3390/su11164481.

Hammershøj, L. (2019), "The new division of labor between human and machine and its educational implications", Technology in Society, Vol. 59, 101142. http://dx.doi.org/10.1016/j.techsoc.2019.05.006.

Hancock, D. and Algozzine, B. (2016), Doing Case Study Research: a Practical Guide for Beginning Researchers, Teachers College Press, New York.

Haugaard, M. (2020), "The faces of power, resistance and justification in a changing world", Journal of Political Power, Vol. 13, No. 1, pp. 1-5. http://dx.doi.org/10.1080/2158379X.2020.1723954.

Holcombe, R. (2020), “Political power", in Holcombe, R.G. (Ed.), Coordination, Cooperation, and Control, Palgrave Macmillan, Cham, pp. 21-44. http://dx.doi.org/10.1007/978-3-030-48667-9_2.

Huang, M. and Rust, R. (2018), "Artificial intelligence in service", Journal of Service Research, Vol. 21, No. 2, pp. 155-72. http://dx.doi.org/10.1177/1094670517752459.

Huang, M. and Rust, R. (2020), "Engaged to a robot? The role of ai in service", Journal of Service Research, In press. http://dx.doi.org/10.1177/1094670520902266.

Huang, M., Rust, R. and Maksimovic, V. (2019), "The feeling economy: managing in the next generation of Artificial Intelligence (AI)", California Management Review, Vol. 61, No. 4, pp. 43-65. http://dx.doi.org/10.1177/0008125619863436.

Ivanov, S. (2020), "The impact of automation on tourism and hospitality jobs", Information Technology \& Tourism, Vol. 22, pp. 205-215. http://dx.doi.org/10.1007/s40558-020-00175-1.

Jarrahi, M. (2018), "Artificial intelligence and the future of work: human-Al symbiosis in organizational decision making", Business Horizons, Vol. 61, No. 4, pp. 577-86. http://dx.doi.org/10.1016/j.bushor.2018.03.007.

Journal of Political Power (2020), "Aim and scope", available at: https://www.tandfonline.com/ action/journallnformation?show=aimsScope\&journalCode=rpow21 (accessed 8 September 2020).

Kaplan, A. and Haenlein, M. (2020), "Rulers of the world, unite! The challenges and opportunities of artificial intelligence", Business Horizons, Vol. 63, No. 1, pp. 37-50. http://dx.doi.org/10.1016/j.bushor.2019.09.003.

Kapustina, L., Lipková, L., Silin, Y. et al. (2020), “US-China trade war: causes and outcomes", SHS Web of Conferences, Vol. 73, 01012. http://dx.doi.org/10.1051/shsconf/20207301012.

Kelso, L. and Adler, M. (1958), The Capitalist Manifesto, Random House, New York.

Kihlstrom, J. and Cantor, N. (2000), "Social intelligence", Handbook of Intelligence, Vol. 2, pp. 359-379. http://dx.doi.org/10.1017/CBO9780511807947.017.

Kokkinakos, P., Markaki, O., Koussouris, S. et al. (2016), “Digital transformation: is public sector following the enterprise 2.0 paradigm?", in Chugunov, A., Bolgov, R., Kabanov, Y. et al. (Eds.), Digital Transformation and Global Society, Springer, Cham, pp. 96-105. http://dx.doi.org/10.1007/978-3-31949700-6_11.

Krippendorff, K. (2018), Content Analysis: an Introduction to its Methodology, Sage Publications, Beverly Hills.

Lauterbach, A. (2019), "Artificial intelligence and policy: quo vadis", Digital Policy, Regulation and Governance, Vol. 21, No. 3, pp. 238-63. http://dx.doi.org/10.1108/DPRG-09-2018-0054.

Li, D. and Du, Y. (2017), Artificial Intelligence with Uncertainty, CRC Press, Beijing.

Li, J., Bonn, M. and Ye, B. (2019), "Hotel employee's artificial intelligence and robotics awareness and its impact on turnover intention: the moderating roles of perceived organizational support and competitive psychological climate", Tourism Management, Vol. 73, pp. 172-81. http://dx.doi.org/10.1016/j.tourman.2019.02.006.

Lloyd, C. and Payne, J. (2019), "Rethinking country effects: robotics, Al and work futures in Norway and the UK", New Technology, Work and Employment, Vol. 34, No. 3, pp. 208-25.

Lu, V., Wirtz, J., Kunz, W. et al. (2020), "Service robots, customers and service employees: what can we learn from the academic literature and where are the gaps", Journal of Service Theory and Practice, Vol. 30, No. 3, pp. 361-391. http://dx.doi.org/10.1108/JSTP-04-2019-0088. 
Makridakis, S. (2017), "The forthcoming Artificial Intelligence (Al) revolution: its impact on society and firms", Futures, Vol. 90, pp. 46-60. http://dx.doi.org/10.1016/j.futures.2017.03.006.

Marengo, L. (2019), "Is this time different? A note on automation and labour in the fourth industrial revolution", Economia e Politica Industriale, Vol. 46, No. 3, pp. 323-31. http://dx.doi.org/10.1007/s40812-019-00123-z.

Marr, B. (2019), Artificial Intelligence in Practice: How 50 Successful Companies Used Al and Machine Learning to Solve Problems, John Wiley \& Sons, Chichester.

Mayer, J. and Geher, G. (1996), "Emotional intelligence and the identification of emotion", Intelligence, Vol. 22, No. 2, pp. 89-113. http://dx.doi.org/10.1016/S0160-2896(96)90011-2.

Mercer, S. (2020), "The limitations of european data protection as a model for global privacy regulation", AJIL Unbound, Vol. 114, pp. 20-5. http://dx.doi.org/10.1017/aju.2019.83.

Mosteanu, N. (2020), "Artificial intelligence and cyber security: a shield against cyberattack as a risk business management tool-case of european countries", Calitatea, Vol. 21, No. 175, pp. 148-56.

Nam, T. (2019), "Technology usage, expected job sustainability, and perceived job insecurity", Technological Forecasting and Social Change, Vol. 138, pp. 155-65. http://dx.doi.org/10.1016/j.techfore.2018.08.017.

Neuendorf, K. (2016), The Content Analysis Guidebook, Sage Publications, Los Angeles.

Newsome, S., Day, A. and Catano, V. (2000), "Assessing the predictive validity of emotional intelligence", Personality and Individual Differences, Vol. 29, No. 6, pp. 1005-16. http://dx.doi.org/10.1016/S01918869(99)00250-0.

Nilsson, N. (1985), "Artificial intelligence, employment, and income", Human Systems Management, Vol. 5, No. 2, pp. 123-35. http://dx.doi.org/10.3233/HSM-1985-5205.

NVivo (2020), "Fueling academic research", QSR International, available at: https://www.qsrinternational. com/nvivo-qualitative-data-analysis-software/about/nvivo/who-its-for/academia (accessed 24 May 2020).

Parsons, T. (1963), "On the concept of political power", Proceedings of the American Philosophical Society, Vol. 107, No. 3, pp. 232-62.

Petticrew, M. and Roberts, H. (2008), Systematic Reviews in the Social Sciences: A Practical Guide, John Wiley \& Sons, Oxford.

Reis, J., Amorim, M., Melão, N. et al. (2018), “Digital transformation: a literature review and guidelines for future research", in Rocha, A., Adeli, H., Reis, L. et al. (Eds.), World Conference on Information Systems and Technologies, Springer, Cham, pp. 411-421. http://dx.doi.org/10.1007/978-3-319-77703-0_41.

Reis, J., Amorim, M. and Melão, N. (2019a), "Multichannel service failure and recovery in a O2O era: a qualitative multi-method research in the banking services industry", International Journal of Production Economics, Vol. 215, pp. 24-33. http://dx.doi.org/10.1016/j.ijpe.2018.07.001.

Reis, J., Amorim, M. and Melão, N. (2019b), "Service failure and recovery in technology-based business networks", International Journal of Quality and Service Sciences, Vol. 11, No. 1, pp. 2-15. http://dx.doi.org/10.1108/IJQSS-10-2017-0094.

Reis, J., Santo, P. and Melão, N. (2019c), "Impacts of artificial intelligence on public administration: a systematic literature review", in Proceedings of the $14^{\text {th }}$ IEEE Iberian Conference on Information Systems and Technologies, IEEE, Coimbra, Portugal, pp. 1-7. http://dx.doi.org/10.23919/CISTI.2019.8760893.

Reis, J., Amorim, M., Cohen, Y. et al. (2020a), "Artificial intelligence in service delivery systems: a systematic literature review", in Rocha, A., Adeli, H., Reis, L. et al. (Eds.), Trends and Innovations in Information Systems and Technologies, WorldCIST 2020, Advances in Intelligent Systems and Computing, Vol. 1159, Springer, Cham, pp. 222-233. https://doi.org/10.1007/978-3-030-45688-7_23.

Reis, J., Santo, P. and Melão, N. (2020b), “Artificial intelligence theory in service management”, in in Nóvoa, H., Drăgoicea, M., Kühl, N. (Eds.), International Conference on Exploring Services Science, Springer, Cham, pp. 137-149. http://dx.doi.org/10.1007/978-3-030-38724-2_10.

Reis, J., Amorim, M. and Melão, N. (2020c), "Emergent digital strategies and networks: advancements to service management research", Journal of Reviews on Global Economics, Vol. 8, pp. 1689-708. http://dx.doi.org/10.6000/1929-7092.2019.08.152.

Reis, J., Santo, P. and Melão, N. (2020d), "Impact of artificial intelligence research on politics of the European Union member states: the case study of Portugal", Sustainability, Vol. 12, No. 17, pp. 6708. http://dx.doi.org/10.3390/su12176708. 
Rosete, A., Soares, B., Salvadorinho, J. et al. (2020), "Service robots in the hospitality industry: an exploratory literature review", in Nóvoa, H., Drăgoicea, M., Kühl, N. (Eds.), International Conference on Exploring Services Science, Springer, Cham, pp. 174-186. http://dx.doi.org/10.1007/978-3-030-387242_13.

Russell, S. and Norvig, P. (2016), Artificial Intelligence: a Modern Approach, Pearson, Education Limited.

Sachs, J. (2019), "Some brief reflections on digital technologies and economic development", Ethics \& International Affairs, Vol. 33, No. 2, pp. 159-67. http://dx.doi.org/10.1017/S0892679419000133.

Schou, J. and Hjelholt, M. (2018), Digitalization and Public Sector Transformations, Palgrave, Copenhagen. http://dx.doi.org/10.1007/978-3-319-76291-3.

Shapiro, T. and Nieman-Gonder, J. (2006), "Effect of communication mode in justice-based service recovery", Managing Service Quality, Vol. 16, No. 2, pp. 124-44. http://dx.doi.org/10.1108/09604520610650619.

Sharma, G., Yadav, A. and Chopra, R. (2020), "Artificial intelligence and effective governance: a review, critique and research agenda", Sustainable Futures, Vol. 2, pp. 100004. http://dx.doi.org/ 10.1016/j.sftr.2019.100004.

Sousa, W., Melo, E., Bermejo, P. et al. (2019), "How and where is artificial intelligence in the public sector going? A literature review and research agenda", Government Information Quarterly, Vol. 36, No. 4, pp. 101392. http://dx.doi.org/10.1016/j.giq.2019.07.004.

Sternberg, R. (1996), Successful Intelligence: How Practical and Creative Intelligence Determine Success in Life, Simon \& Schuster, New York.

Thorndike, E. (1920), "Intelligence and its uses", Harper's Magazine, Vol. 140, pp. 227-235.

Tien, J. (2020), "Toward the Fourth Industrial Revolution on Real-Time Customization", Journal of Systems Science and Systems Engineering, Vol. 29, No. 2, pp. 127-42. http://dx.doi.org/10.1007/s11518-0195433-9.

Tigner, R. and Tigner, S. (2000), "Triarchic theories of intelligence: Aristotle and Sternberg", History of Psychology, Vol. 3, No. 2, pp. 168-76. http://dx.doi.org/10.1037/1093-4510.3.2.168.

Tranfield, D., Denyer, D. and Smart, P. (2003), "Towards a methodology for developing evidence-informed management knowledge by means of systematic review", British Journal of Management, Vol. 14, No. 3, pp. 207-22. http://dx.doi.org/10.1111/1467-8551.00375.

Turing, A. (1950), "Computing machinery and intelligence", Mind, Vol. 59, No. 236, pp. $433-60$. http://dx.doi.org/10.1093/mind/LIX.236.433.

Walsh, T. (2018), "Expert and non-expert opinion about technological unemployment", International Journal of Automation and Computing, Vol. 15, No. 5, pp. 637-42. http://dx.doi.org/10.1007/s11633018-1127-x.

West, D. (2015), What Happens if Robots Take the Jobs? The Impact of Emerging Technologies on Employment and Public Policy, Centre for Technology Innovation at Brookings, Washington DC.

Wirtz, B. and Müller, W. (2019), "An integrated artificial intelligence framework for public management", Public Management Review, Vol. 21, No. 7, pp. 1076-100. http://dx.doi.org/10.1080/14719037.2018.1549268.

Wirtz, J., Patterson, P., Kunz, W. et al. (2018), "Brave new world: service robots in the frontline", Journal of Service Management, Vol. 29, No. 5, pp. 907-31. http://dx.doi.org/10.1108/JOSM-04-2018-0119.

Woolf, N. and Silver, C. (2017), Qualitative Analysis Using NVivo: the Five-Level QDA® Method, Routledge, Taylor \& Francis Group, New York.

Authors contributions: All authors contributed equally to this paper. 


\section{APPENDIX A. ARTICLE INFORMATION}

\begin{tabular}{|c|c|c|c|}
\hline Authors & Year & Title & Source \\
\hline Lloyd C. and Payne J. & 2019 & $\begin{array}{l}\text { Rethinking country effects: robotics, Al } \\
\text { and work futures in Norway and the UK }\end{array}$ & $\begin{array}{l}\text { New Technology, } \\
\text { Work and } \\
\text { Employment }\end{array}$ \\
\hline Hammershøj L. & 2019 & $\begin{array}{c}\text { The new division of labor between } \\
\text { human and machine and its educational } \\
\text { implications }\end{array}$ & $\begin{array}{l}\text { Technology in } \\
\text { Society }\end{array}$ \\
\hline Xu et al. & 2019 & $\begin{array}{l}\text { Are emotionally intelligent people more } \\
\text { creative? A meta-analysis of the } \\
\text { emotional intelligence-creativity link }\end{array}$ & $\begin{array}{l}\text { Sustainability } \\
\text { (Switzerland) }\end{array}$ \\
\hline Bogoviz et al. & 2019 & $\begin{array}{l}\text { Diversification of educational services in } \\
\text { the conditions of industry } 4.0 \text { on the } \\
\text { basis of Al training }\end{array}$ & On the Horizon \\
\hline AlZu'bi et al. & 2019 & $\begin{array}{l}\text { An efficient employment of internet of } \\
\text { multimedia things in smart and future } \\
\text { agriculture }\end{array}$ & $\begin{array}{l}\text { Multimedia Tools } \\
\text { and Applications }\end{array}$ \\
\hline Rasiah et al. & 2019 & $\begin{array}{l}\text { The impact of emotional intelligence on } \\
\text { work performance: Perceptions and } \\
\text { reflections from academics in Malaysian } \\
\text { higher EducationObitat endiaest que }\end{array}$ & $\begin{array}{l}\text { Contemporary } \\
\text { Economics }\end{array}$ \\
\hline Marengo L. & 2019 & $\begin{array}{l}\text { Is this time different? A note on } \\
\text { automation and labour in the fourth } \\
\text { industrial revolution }\end{array}$ & $\begin{array}{l}\text { Journal of } \\
\text { Industrial and } \\
\text { Business } \\
\text { Economics }\end{array}$ \\
\hline Li et al. & 2019 & $\begin{array}{l}\text { Hotel employee's artificial intelligence } \\
\text { and robotics awareness and its impact } \\
\text { on turnover intention: The moderating } \\
\text { roles of perceived organizational } \\
\text { support and competitive psychological } \\
\text { climate }\end{array}$ & $\begin{array}{l}\text { Tourism } \\
\text { Management }\end{array}$ \\
\hline Hall et al. & 2019 & $\begin{array}{l}\text { Universal basic income and inclusive } \\
\text { capitalism: Consequences for } \\
\text { sustainability }\end{array}$ & $\begin{array}{l}\text { Sustainability } \\
\text { (Switzerland) }\end{array}$ \\
\hline Marinoudi et al. & 2019 & $\begin{array}{l}\text { Robotics and labour in agriculture. A } \\
\text { context consideration }\end{array}$ & $\begin{array}{l}\text { Biosystems } \\
\text { Engineering }\end{array}$ \\
\hline Ravi Chander et al. & 2019 & $\begin{array}{l}\text { Modeling and model analysis of an } \\
\text { industrial robot arm for pick and drop } \\
\text { circular motion using different materials }\end{array}$ & $\begin{array}{l}\text { International } \\
\text { Journal of } \\
\text { Engineering and } \\
\text { Advanced } \\
\text { Technology }\end{array}$ \\
\hline Morgan J. & 2019 & $\begin{array}{l}\text { Will we work in twenty-first century } \\
\text { capitalism? A critique of the fourth } \\
\text { industrial revolution literature }\end{array}$ & $\begin{array}{l}\text { Economy and } \\
\text { Society }\end{array}$ \\
\hline Sahota N. and Ashley M. & 2019 & $\begin{array}{l}\text { When Robots Replace Human Managers: } \\
\text { Introducing the Quantifiable Workplace }\end{array}$ & $\begin{array}{l}\text { IEEE Engineering } \\
\text { Management } \\
\text { Review }\end{array}$ \\
\hline $\begin{array}{l}\text { Nazim Sha S. and } \\
\text { Rajeswari M. }\end{array}$ & 2019 & $\begin{array}{l}\text { Creating a brand value and consumer } \\
\text { satisfaction in E-commerce business } \\
\text { using artificial intelligence with the help } \\
\text { of vosag technology }\end{array}$ & $\begin{array}{l}\text { International } \\
\text { Journal of } \\
\text { Innovative } \\
\text { Technology and } \\
\text { Exploring } \\
\text { Engineering }\end{array}$ \\
\hline
\end{tabular}




\begin{tabular}{|c|c|c|c|}
\hline Authors & Year & Title & Source \\
\hline Lauterbach A. & 2019 & $\begin{array}{l}\text { Artificial intelligence and policy: quo } \\
\text { vadis? }\end{array}$ & $\begin{array}{l}\text { Digital Policy, } \\
\text { Regulation and } \\
\text { Governance }\end{array}$ \\
\hline $\begin{array}{l}\text { Garcia-Murillo M. and } \\
\text { MacInnes I. }\end{array}$ & 2019 & $\begin{array}{l}\text { Al's path to the present and the painful } \\
\text { transitions along the way }\end{array}$ & $\begin{array}{l}\text { Digital Policy, } \\
\text { Regulation and } \\
\text { Governance }\end{array}$ \\
\hline Verma S. and Sharma A. & 2019 & $\begin{array}{l}\text { Artificial intelligence: employment and } \\
\text { society }\end{array}$ & $\begin{array}{l}\text { International } \\
\text { Journal of } \\
\text { Innovative } \\
\text { Technology and } \\
\text { Exploring } \\
\text { Engineering }\end{array}$ \\
\hline Ravi et al. & 2019 & $\begin{array}{l}\text { Artificial intelligence-will it hasten or } \\
\text { hamper women career progression }\end{array}$ & $\begin{array}{l}\text { International } \\
\text { Journal of Recent } \\
\text { Technology and } \\
\text { Engineering }\end{array}$ \\
\hline Ilie et al. & 2019 & $\begin{array}{l}\text { Sustainability through the use of modern } \\
\text { simulation methods-Applied artificial } \\
\text { intelligence }\end{array}$ & $\begin{array}{l}\text { Sustainability } \\
\text { (Switzerland) }\end{array}$ \\
\hline Chen et al. & 2019 & $\begin{array}{l}\text { An enhanced lightweight dynamic } \\
\text { pseudonym identity based } \\
\text { authentication and key agreement } \\
\text { scheme using wireless sensor networks } \\
\text { for agriculture monitoring }\end{array}$ & $\begin{array}{c}\text { Sensors } \\
\text { (Switzerland) }\end{array}$ \\
\hline $\begin{array}{c}\text { Richardson L. and Bissell } \\
\text { D. }\end{array}$ & 2019 & Geographies of digital skill & Geoforum \\
\hline Liu T. and Wang C. & 2019 & $\begin{array}{l}\text { Intangible welfare? The new economy } \\
\text { and social policy in China }\end{array}$ & $\begin{array}{l}\text { Journal of Asian } \\
\text { Public Policy }\end{array}$ \\
\hline Zhou et al. & 2019 & $\begin{array}{l}\text { The effect of artificial intelligence on } \\
\text { China's labor market }\end{array}$ & $\begin{array}{l}\text { China Economic } \\
\text { Journal }\end{array}$ \\
\hline Kovacova et al. & 2019 & $\begin{array}{l}\text { Automating gender roles at work: How } \\
\text { digital disruption and artificial } \\
\text { intelligence alter industry structures and } \\
\text { sex-based divisions of labor }\end{array}$ & $\begin{array}{l}\text { Journal of } \\
\text { Research in } \\
\text { Gender Studies }\end{array}$ \\
\hline $\begin{array}{l}\text { Kaplan A. and Haenlein } \\
\text { M. }\end{array}$ & 2019 & $\begin{array}{l}\text { Rulers of the world, unite! The } \\
\text { challenges and opportunities of artificial } \\
\text { intelligence }\end{array}$ & Business Horizons \\
\hline Hrustek et al. & 2019 & $\begin{array}{l}\text { Developing and validating measurement } \\
\text { instrument for various aspects of digital } \\
\text { economy: E-commerce, E-banking, E- } \\
\text { work and E-employment }\end{array}$ & $\begin{array}{l}\text { International } \\
\text { Journal of E- } \\
\text { Services and } \\
\quad \text { Mobile } \\
\text { Applications }\end{array}$ \\
\hline Sachs J. & 2019 & $\begin{array}{c}\text { Some Brief Reflections on Digital } \\
\text { Technologies and Economic } \\
\text { Development }\end{array}$ & $\begin{array}{l}\text { Ethics and } \\
\text { International } \\
\text { Affairs }\end{array}$ \\
\hline Fleming $P$. & 2019 & $\begin{array}{l}\text { Robots and Organization Studies: Why } \\
\text { Robots Might Not Want to Steal Your Job }\end{array}$ & $\begin{array}{l}\text { Organization } \\
\text { Studies }\end{array}$ \\
\hline Tien J. & 2019 & $\begin{array}{l}\text { Toward the Fourth Industrial Revolution } \\
\text { on Real-Time Customization }\end{array}$ & $\begin{array}{l}\text { Journal of Systems } \\
\text { Science and } \\
\text { Systems } \\
\text { Engineering }\end{array}$ \\
\hline Nam T. & 2019 & $\begin{array}{l}\text { Technology usage, expected job } \\
\text { sustainability, and perceived job } \\
\text { insecurity }\end{array}$ & $\begin{array}{l}\text { Technological } \\
\text { Forecasting and } \\
\text { Social Change }\end{array}$ \\
\hline
\end{tabular}




\begin{tabular}{|c|c|c|c|}
\hline Authors & Year & Title & Source \\
\hline Udell et al. & 2019 & $\begin{array}{l}\text { Towards a smart automated society: } \\
\text { Cognitive technologies, knowledge } \\
\text { production, and economic growth }\end{array}$ & $\begin{array}{c}\text { Economics, } \\
\text { Management, and } \\
\text { Financial Markets }\end{array}$ \\
\hline Esser et al. & 2019 & $\begin{array}{l}\text { The labour market for the port of the } \\
\text { future. A case study for the port of } \\
\text { Antwerp }\end{array}$ & $\begin{array}{l}\text { Case Studies on } \\
\text { Transport Policy }\end{array}$ \\
\hline Sutherland E. & 2019 & $\begin{array}{l}\text { The Fourth Industrial Revolution-The } \\
\text { Case of South Africa }\end{array}$ & Politikon \\
\hline Vasant et al. & 2019 & $\begin{array}{l}\text { Nature-inspired meta-heuristics } \\
\text { approaches for charging plug-in hybrid } \\
\text { electric vehicle }\end{array}$ & Wireless Networks \\
\hline Kim et al. & 2019 & $\begin{array}{c}\text { Learning-based screening of } \\
\text { hematologic disorders using quantitative } \\
\text { phase imaging of individual red blood } \\
\text { cells }\end{array}$ & $\begin{array}{l}\text { Biosensors and } \\
\text { Bioelectronics }\end{array}$ \\
\hline Pipitone et al. & 2019 & $\begin{array}{l}\text { Building an ANFIS-Based Decision } \\
\text { Support System for Regional Growth: } \\
\text { The Case of European Regions }\end{array}$ & $\begin{array}{l}\text { IEEE Transactions } \\
\text { on Engineering } \\
\text { Management }\end{array}$ \\
\hline $\begin{array}{l}\text { Hoffmann C. and } \\
\text { Dahlinger A. }\end{array}$ & 2019 & $\begin{array}{l}\text { How capitalism abolishes itself in the } \\
\text { digital era in favour of robo-economic } \\
\text { systems: socio-economic implications of } \\
\text { decentralized autonomous self-owned } \\
\text { businesses }\end{array}$ & Foresight \\
\hline Hipel et al. & 2019 & $\begin{array}{c}\text { The Graph Model for Conflict Resolution: } \\
\text { Reflections on Three Decades of } \\
\text { Development }\end{array}$ & $\begin{array}{l}\text { Group Decision } \\
\text { and Negotiation }\end{array}$ \\
\hline Mamedov et al. & 2018 & $\begin{array}{l}\text { Sustainable economic development and } \\
\text { post-economy of artificial intelligence }\end{array}$ & $\begin{array}{l}\text { Entrepreneurship } \\
\text { and Sustainability } \\
\text { Issues }\end{array}$ \\
\hline Yang et al. & 2018 & $\begin{array}{c}\text { Active Learning for Wireless loT Intrusion } \\
\text { Detection }\end{array}$ & $\begin{array}{l}\text { IEEE Wireless } \\
\text { Communications }\end{array}$ \\
\hline Birtchnell T. and Elliott A. & 2018 & $\begin{array}{c}\text { Automating the black art: Creative places } \\
\text { for artificial intelligence in audio } \\
\text { mastering }\end{array}$ & Geoforum \\
\hline Estlund C. & 2018 & $\begin{array}{l}\text { What should we do after work? } \\
\text { Automation and employment law }\end{array}$ & Yale Law Journal \\
\hline Walsh T. & 2018 & $\begin{array}{l}\text { Expert and Non-expert Opinion About } \\
\text { Technological Unemployment }\end{array}$ & $\begin{array}{l}\text { International } \\
\text { Journal of } \\
\text { Automation and } \\
\text { Computing }\end{array}$ \\
\hline Berger et al. & 2018 & $\begin{array}{l}\text { Intelligent co-simulation: neural network } \\
\text { vs. proper orthogonal decomposition } \\
\text { applied to a 2D diffusive problem }\end{array}$ & $\begin{array}{l}\text { Journal of Building } \\
\text { Performance } \\
\text { Simulation }\end{array}$ \\
\hline Boyd R. and Holton R. & 2018 & $\begin{array}{l}\text { Technology, innovation, employment } \\
\text { and power: Does robotics and artificial } \\
\text { intelligence really mean social } \\
\text { transformation? }\end{array}$ & $\begin{array}{l}\text { Journal of } \\
\text { Sociology }\end{array}$ \\
\hline Michailidis M. & 2018 & $\begin{array}{c}\text { The challenges of } \mathrm{Al} \text { and blockchain on } \\
\text { HR recruiting practices }\end{array}$ & Cyprus Review \\
\hline De Mauro et al. & 2018 & $\begin{array}{l}\text { Human resources for Big Data } \\
\text { professions: A systematic classification } \\
\text { of job roles and required skill sets }\end{array}$ & $\begin{array}{l}\text { Information } \\
\text { Processing and } \\
\text { Management }\end{array}$ \\
\hline Turner Lee N. & 2018 & $\begin{array}{c}\text { Detecting racial bias in algorithms and } \\
\text { machine learning }\end{array}$ & $\begin{array}{l}\text { Journal of } \\
\text { Information, }\end{array}$ \\
\hline
\end{tabular}




\begin{tabular}{|c|c|c|c|}
\hline Authors & Year & Title & Source \\
\hline & & & $\begin{array}{l}\text { Communication } \\
\text { and Ethics in } \\
\text { Society }\end{array}$ \\
\hline Kim et al. & 2018 & $\begin{array}{l}\text { BIM-Driven Automated Decision Support } \\
\text { System for Safety Planning of Temporary } \\
\text { Structures }\end{array}$ & $\begin{array}{l}\text { Journal of } \\
\text { Construction } \\
\text { Engineering and } \\
\text { Management }\end{array}$ \\
\hline Avis J. & 2018 & $\begin{array}{c}\text { Socio-technical imaginary of the fourth } \\
\text { industrial revolution and its implications } \\
\text { for vocational education and training: a } \\
\text { literature review }\end{array}$ & $\begin{array}{l}\text { Journal of } \\
\text { Vocational } \\
\text { Education and } \\
\text { Training }\end{array}$ \\
\hline Pham et al. & 2018 & $\begin{array}{l}\text { The Impact of Robotics and Automation } \\
\text { on Working Conditions and Employment }\end{array}$ & $\begin{array}{l}\text { IEEE Robotics and } \\
\text { Automation } \\
\text { Magazine }\end{array}$ \\
\hline Dalenberg D. & 2018 & $\begin{array}{l}\text { Preventing discrimination in the } \\
\text { automated targeting of job } \\
\text { advertisements }\end{array}$ & $\begin{array}{l}\text { Computer Law and } \\
\text { Security Review }\end{array}$ \\
\hline Stringer $\mathrm{J}$. & 2018 & $\begin{array}{l}\text { Changing character, changing con text: } \\
\text { Enhancing operational airpower } \\
\text { employment in the RAF's second century }\end{array}$ & RUSI Journal \\
\hline Huang M.-H., Rust R.T., & 2018 & Artificial Intelligence in Service & $\begin{array}{l}\text { Journal of Service } \\
\text { Research }\end{array}$ \\
\hline Boldsen et al. & 2018 & $\begin{array}{l}\text { Better diffusion segmentation in acute } \\
\text { ischemic stroke through automatic tree } \\
\text { learning anomaly segmentation }\end{array}$ & $\begin{array}{l}\text { Frontiers in } \\
\text { Neuroinformatics }\end{array}$ \\
\hline Nica et al. & 2018 & $\begin{array}{l}\text { A laborless society? How highly } \\
\text { automated environments and } \\
\text { breakthroughs in artificial intelligence } \\
\text { bring about innovative kinds of skills and } \\
\text { employment disruptions, altering the } \\
\text { nature of business process and affecting } \\
\text { the path of economic growth }\end{array}$ & $\begin{array}{l}\text { Journal of Self- } \\
\text { Governance and } \\
\text { Management } \\
\text { Economics }\end{array}$ \\
\hline Frank et al. & 2018 & $\begin{array}{l}\text { Small cities face greater impact from } \\
\text { automation }\end{array}$ & $\begin{array}{l}\text { Journal of the } \\
\text { Royal Society } \\
\text { Interface }\end{array}$ \\
\hline Budanov et al. & 2018 & Industry 4.0.: Socio-economic junctures & $\begin{array}{l}\text { Economic Annals- } \\
\qquad X X I\end{array}$ \\
\hline Nakatani et al. & 2017 & $\begin{array}{l}\text { Promotion of self-growth of students by } \\
\text { PBL-type manufacturing practice }\end{array}$ & $\begin{array}{l}\text { Journal of Robotics } \\
\text { and Mechatronics }\end{array}$ \\
\hline Peker et al. & 2017 & $\begin{array}{c}\text { A new fuzzy logic based career guidance } \\
\text { system: WEB-CGS [Novi sustav } \\
\text { profesionalnog usmjeravanja zasnovan } \\
\text { na neizrazitoj logici: WEB-CGS] }\end{array}$ & Tehnicki Vjesnik \\
\hline McCrum D. & 2017 & $\begin{array}{c}\text { Evaluation of creative problem-solving } \\
\text { abilities in undergraduate structural } \\
\text { engineers through interdisciplinary } \\
\text { problem-based learning }\end{array}$ & $\begin{array}{l}\text { European Journal } \\
\text { of Engineering } \\
\text { Education }\end{array}$ \\
\hline Fox S. & 2017 & $\begin{array}{l}\text { Mass imagineering: Combining human } \\
\text { imagination and automated engineering } \\
\text { from early education to digital afterlife }\end{array}$ & $\begin{array}{l}\text { Technology in } \\
\text { Society }\end{array}$ \\
\hline Arlitsch K. and Newell B. & 2017 & $\begin{array}{l}\text { Thriving in the Age of Accelerations: A } \\
\text { Brief Look at the Societal Effects of } \\
\text { Artificial Intelligence and the } \\
\text { Opportunities for Libraries }\end{array}$ & $\begin{array}{l}\text { Journal of Library } \\
\text { Administration }\end{array}$ \\
\hline
\end{tabular}




\begin{tabular}{|c|c|c|c|}
\hline Authors & Year & Title & Source \\
\hline $\begin{array}{l}\text { Etzkowitz A. and } \\
\text { Etzkowitz } \mathrm{H} \text {. }\end{array}$ & 2017 & $\begin{array}{c}\text { Counter-cyclical public venture capital: } \\
\text { Debt-funding as an anti-austerity } \\
\text { innovation strategy }\end{array}$ & $\begin{array}{l}\text { Social Science } \\
\text { Information }\end{array}$ \\
\hline Jiang et al. & 2017 & $\begin{array}{l}\text { Machine Learning Paradigms for Next- } \\
\text { Generation Wireless Networks }\end{array}$ & $\begin{array}{l}\text { IEEE Wireless } \\
\text { Communications }\end{array}$ \\
\hline Morikawa M. & 2017 & $\begin{array}{l}\text { Firms' Expectations about the Impact of } \\
\text { Al and Robotics: Evidence from a Survey }\end{array}$ & Economic Inquiry \\
\hline Dabirian et al. & 2017 & $\begin{array}{l}\text { A great place to work!? Understanding } \\
\text { crowdsourced employer branding }\end{array}$ & Business Horizons \\
\hline Zhu C. & 2017 & $\begin{array}{l}\text { Construction and research on the } \\
\text { personalized employment } \\
\text { recommendation system for college } \\
\text { students based on hadoop platform }\end{array}$ & $\begin{array}{l}\text { Boletin } \\
\text { Tecnico/Technical } \\
\text { Bulletin }\end{array}$ \\
\hline Mansell R. & 2017 & $\begin{array}{l}\text { The mediation of hope: Communication } \\
\text { technologies and inequality in } \\
\text { perspective }\end{array}$ & $\begin{array}{l}\text { International } \\
\text { Journal of } \\
\text { Communication }\end{array}$ \\
\hline Gratton L. & 2017 & Change Management & $\begin{array}{l}\text { London Business } \\
\text { School Review }\end{array}$ \\
\hline Pyka A. & 2017 & $\begin{array}{l}\text { Dedicated innovation systems to } \\
\text { support the transformation towards } \\
\text { sustainability: Creating income } \\
\text { opportunities and employment in the } \\
\text { knowledge-based digital bioeconomy }\end{array}$ & $\begin{array}{l}\text { Journal of Open } \\
\text { Innovation: } \\
\text { Technology, } \\
\text { Market, and } \\
\text { Complexity }\end{array}$ \\
\hline Chien et al. & 2017 & $\begin{array}{l}\text { Injury severity measures for predicting } \\
\text { return-to-work after a traumatic brain } \\
\text { injury }\end{array}$ & $\begin{array}{l}\text { Accident Analysis } \\
\text { and Prevention }\end{array}$ \\
\hline Swanson J. & 2017 & The future of student life: working & On the Horizon \\
\hline Simpson B. & 2016 & $\begin{array}{l}\text { Algorithms or advocacy: does the legal } \\
\text { profession have a future in a digital } \\
\text { world? }\end{array}$ & $\begin{array}{l}\text { Information and } \\
\text { Communications } \\
\text { Technology Law }\end{array}$ \\
\hline Hirsch P. & 2016 & The Caliphate of numbers & $\begin{array}{c}\text { Journal of Business } \\
\text { Strategy }\end{array}$ \\
\hline Coeckelbergh M. & 2015 & $\begin{array}{l}\text { The tragedy of the master: automation, } \\
\text { vulnerability, and distance }\end{array}$ & $\begin{array}{l}\text { Ethics and } \\
\text { Information } \\
\text { Technology }\end{array}$ \\
\hline Jiang et al. & 2015 & $\begin{array}{l}\text { Mining point-of-interest data from social } \\
\text { networks for urban land use } \\
\text { classification and disaggregation }\end{array}$ & $\begin{array}{l}\text { Computers, } \\
\text { Environment and } \\
\text { Urban Systems }\end{array}$ \\
\hline Loi M. & 2015 & $\begin{array}{l}\text { Technological unemployment and } \\
\text { human disenhancement }\end{array}$ & $\begin{array}{l}\text { Ethics and } \\
\text { Information } \\
\text { Technology }\end{array}$ \\
\hline Amanatiadis et al. & 2015 & $\begin{array}{l}\text { Accelerating single-image super- } \\
\text { resolution polynomial regression in } \\
\text { mobile devices }\end{array}$ & $\begin{array}{l}\text { IEEE Transactions } \\
\text { on Consumer } \\
\text { Electronics }\end{array}$ \\
\hline Gelashvili et al. & 2015 & $\begin{array}{l}\text { The profitability of socially responsible } \\
\text { companies: Public subsidies for } \\
\text { sheltered employment centers }\end{array}$ & $\begin{array}{l}\text { Ramon Llull } \\
\text { Journal of Applied } \\
\text { Ethics }\end{array}$ \\
\hline Singh K. and Mehta C. & 2015 & $\begin{array}{l}\text { Decision support system for estimating } \\
\text { operating costs and break-even units of } \\
\text { farm machinery }\end{array}$ & $\begin{array}{l}\text { AMA, Agricultural } \\
\text { Mechanization in } \\
\text { Asia, Africa and } \\
\text { Latin America }\end{array}$ \\
\hline Zadorozhnaya et al. & 2015 & $\begin{array}{l}\text { Water pollution monitoring by an } \\
\text { artificial sensory system performing in } \\
\text { terms of Vibrio fischeri bacteria }\end{array}$ & $\begin{array}{l}\text { Sensors and } \\
\text { Actuators, B: } \\
\text { Chemical }\end{array}$ \\
\hline
\end{tabular}




\begin{tabular}{|c|c|c|c|}
\hline Authors & Year & Title & Source \\
\hline Mattar E. & 2013 & $\begin{array}{l}\text { A survey of bio-inspired robotics hands } \\
\text { implementation: New directions in } \\
\text { dexterous manipulation }\end{array}$ & $\begin{array}{l}\text { Robotics and } \\
\text { Autonomous } \\
\text { Systems }\end{array}$ \\
\hline Weber et al. & 2013 & $\begin{array}{c}\text { A study on scale factor/crossover } \\
\text { interaction in distributed differential } \\
\text { evolution }\end{array}$ & $\begin{array}{c}\text { Artificial } \\
\text { Intelligence Review }\end{array}$ \\
\hline Jayachandran et al. & 2013 & $\begin{array}{c}\text { Application of fuzzy logic in PWM } \\
\text { technique and dc link voltage control for } \\
\text { a UPQC system }\end{array}$ & $\begin{array}{l}\text { International } \\
\text { Review on } \\
\text { Modelling and } \\
\text { Simulations }\end{array}$ \\
\hline Sun L. and Chen W. & 2013 & $\begin{array}{l}\text { The improved ChinaCCS decision } \\
\text { support system: A case study for Beijing- } \\
\text { Tianjin-Hebei Region of China }\end{array}$ & Applied Energy \\
\hline Barzanti L. and Giove S. & 2012 & $\begin{array}{l}\text { A decision support system for fund } \\
\text { raising management based on the } \\
\text { Choquet integral methodology }\end{array}$ & Expert Systems \\
\hline Gromov V. and Shulga A. & 2012 & $\begin{array}{l}\text { Chaotic time series prediction with } \\
\text { employment of ant colony optimization }\end{array}$ & $\begin{array}{l}\text { Expert Systems } \\
\text { with Applications }\end{array}$ \\
\hline Derrac et al. & 2012 & $\begin{array}{l}\text { Integrating instance selection, instance } \\
\text { weighting, and feature weighting for } \\
\text { nearest neighbor classifiers by } \\
\text { coevolutionary algorithms }\end{array}$ & $\begin{array}{l}\text { IEEE Transactions } \\
\text { on Systems, Man, } \\
\text { and Cybernetics, } \\
\text { Part B: Cybernetics }\end{array}$ \\
\hline Huang et al. & 2012 & $\begin{array}{l}\text { Determining the number of new } \\
\text { employees with learning, forgetting and } \\
\text { variable wage with a Newsvendor model } \\
\text { in pull systems }\end{array}$ & $\begin{array}{l}\text { Journal of } \\
\text { Intelligent } \\
\text { Manufacturing }\end{array}$ \\
\hline den Herder et al. & 2012 & $\begin{array}{l}\text { Sustainability impact assessment on the } \\
\text { production and use of different wood } \\
\text { and fossil fuels employed for energy } \\
\text { production in North Karelia, Finland }\end{array}$ & Energies \\
\hline $\begin{array}{c}\text { Padma T. and } \\
\text { Balasubramanie P. }\end{array}$ & 2011 & $\begin{array}{l}\text { A fuzzy analytic hierarchy processing } \\
\text { decision support system to analyze } \\
\text { occupational menace forecasting the } \\
\text { spawning of shoulder and neck pain }\end{array}$ & $\begin{array}{l}\text { Expert Systems } \\
\text { with Applications }\end{array}$ \\
\hline Kripakaran et al. & 2011 & $\begin{array}{l}\text { A genetic algorithm for design of } \\
\text { moment-resisting steel frames }\end{array}$ & $\begin{array}{l}\text { Structural and } \\
\text { Multidisciplinary } \\
\text { Optimization }\end{array}$ \\
\hline Kaklauskas et al. & 2011 & $\begin{array}{l}\text { Recommended biometric stress } \\
\text { management system }\end{array}$ & $\begin{array}{l}\text { Expert Systems } \\
\text { with Applications }\end{array}$ \\
\hline Weber et al. & 2011 & $\begin{array}{l}\text { A study on scale factor in distributed } \\
\text { differential evolution }\end{array}$ & $\begin{array}{l}\text { Information } \\
\text { Sciences }\end{array}$ \\
\hline Beetz et al. & 2010 & $\begin{array}{l}\text { Towards performing everyday } \\
\text { manipulation activities }\end{array}$ & $\begin{array}{l}\text { Robotics and } \\
\text { Autonomous } \\
\text { Systems }\end{array}$ \\
\hline Yamagishi et al. & 2009 & $\begin{array}{l}\text { Service cost and utilization rate } \\
\text { optimization in service systems }\end{array}$ & $\begin{array}{l}\text { Journal of } \\
\text { Integrated Design } \\
\text { and Process } \\
\text { Science }\end{array}$ \\
\hline Papakiriakopoulos et al. & 2009 & $\begin{array}{l}\text { A decision support system for detecting } \\
\text { products missing from the shelf based } \\
\text { on heuristic rules }\end{array}$ & $\begin{array}{l}\text { Decision Support } \\
\text { Systems }\end{array}$ \\
\hline Chang $\mathrm{H}$. & 2008 & $\begin{array}{l}\text { Intelligent agent's technology } \\
\text { characteristics applied to online }\end{array}$ & Technovation \\
\hline
\end{tabular}




\begin{tabular}{|c|c|c|c|}
\hline Authors & Year & Title & Source \\
\hline \multicolumn{4}{|c|}{$\begin{array}{c}\text { auctions' task: A combined model of TTF } \\
\text { and TAM }\end{array}$} \\
\hline Meng et al. & 2008 & $\begin{array}{l}\text { Nonlinear dimensionality reduction of } \\
\text { data lying on the multicluster manifold }\end{array}$ & $\begin{array}{l}\text { IEEE Transactions } \\
\text { on Systems, Man, } \\
\text { and Cybernetics, } \\
\text { Part B: Cybernetics }\end{array}$ \\
\hline Blanco et al. & 2008 & $\begin{array}{c}\text { Decision support system for micro-hydro } \\
\text { power plants in the Amazon region } \\
\text { under a sustainable development } \\
\text { perspective }\end{array}$ & $\begin{array}{l}\text { Energy for } \\
\text { Sustainable } \\
\text { Development }\end{array}$ \\
\hline Machado et al. & 2007 & $\begin{array}{l}\text { Ambient intelligence via multiagent } \\
\text { systems in the medical arena }\end{array}$ & $\begin{array}{l}\text { Engineering } \\
\text { Intelligent Systems }\end{array}$ \\
\hline Dobrzański et al. & 2007 & $\begin{array}{l}\text { The use of neural networks for the } \\
\text { classification of casting defect }\end{array}$ & $\begin{array}{l}\text { International } \\
\text { Journal of } \\
\text { Computational } \\
\text { Materials Science } \\
\text { and Surface } \\
\text { Engineering }\end{array}$ \\
\hline Cao et al. & 2007 & $\begin{array}{l}\text { Assembly planning using a novel } \\
\text { immune approach }\end{array}$ & $\begin{array}{l}\text { International } \\
\text { Journal of } \\
\text { Advanced } \\
\text { Manufacturing } \\
\text { Technology }\end{array}$ \\
\hline Amigoni et al. & 2006 & $\begin{array}{l}\text { Agencies for perception in } \\
\text { environmental monitoring }\end{array}$ & $\begin{array}{l}\text { IEEE Transactions } \\
\text { on } \\
\text { Instrumentation } \\
\text { and Measurement }\end{array}$ \\
\hline Yagci et al. & 2005 & $\begin{array}{l}\text { Artificial intelligence methods in } \\
\text { breakwater damage ratio estimation }\end{array}$ & Ocean Engineering \\
\hline Gustavsson E. & 2005 & $\begin{array}{l}\text { Virtual servants: Stereotyping female } \\
\text { front-office employees on the Internet }\end{array}$ & $\begin{array}{l}\text { Gender, Work and } \\
\text { Organization }\end{array}$ \\
\hline Šef T. and Gams M. & 2003 & $\begin{array}{l}\text { Speaker (GOVOREC): A complete } \\
\text { Slovenian text-to speech system }\end{array}$ & $\begin{array}{l}\text { International } \\
\text { Journal of Speech } \\
\text { Technology }\end{array}$ \\
\hline Li et al. & 2001 & $\begin{array}{l}\text { A Web-based tool and a heuristic } \\
\text { method for cooperation of } \\
\text { manufacturing supply chain decisions }\end{array}$ & $\begin{array}{l}\text { Journal of } \\
\text { Intelligent } \\
\text { Manufacturing }\end{array}$ \\
\hline Gams M. and Sef T. & 2000 & A speech module in an agent system & $\begin{array}{c}\text { International } \\
\text { Journal of } \\
\text { Engineering } \\
\text { Intelligent Systems } \\
\text { for Electrical } \\
\text { Engineering and } \\
\text { Communications }\end{array}$ \\
\hline Schell C. & 1997 & Working at Uncle Sam's & IEEE Potentials \\
\hline Akama et al. & 1997 & $\begin{array}{c}\text { Common structure of semi-thue } \\
\text { systems, petri nets, and other rewriting } \\
\text { systems }\end{array}$ & $\begin{array}{l}\text { IEICE Transactions } \\
\text { on Information } \\
\text { and Systems }\end{array}$ \\
\hline Karagiannidis et al. & 1997 & $\begin{array}{l}\text { Adaptation in IMMPS as a decision } \\
\text { making process }\end{array}$ & $\begin{array}{l}\text { Computer } \\
\text { Standards and } \\
\text { Interfaces }\end{array}$ \\
\hline Gondles Jr. & 1996 & A frontline view of the future of prisons & Prison Journal \\
\hline Binbasioglu et al. & 1996 & $\begin{array}{l}\text { A synthesizing framework for decision } \\
\text { support systems applications }\end{array}$ & $\begin{array}{l}\text { Journal of } \\
\text { Computer }\end{array}$ \\
\hline
\end{tabular}




\begin{tabular}{|c|c|c|c|}
\hline Authors & Year & Title & Source \\
\hline & & & $\begin{array}{l}\text { Information } \\
\text { Systems }\end{array}$ \\
\hline Blitch J. & 1996 & $\begin{array}{l}\text { Artificial intelligence technologies for } \\
\text { robot assisted urban search and rescue }\end{array}$ & $\begin{array}{l}\text { Expert Systems } \\
\text { with Applications }\end{array}$ \\
\hline Frank P. and Kiupel N. & 1993 & $\begin{array}{l}\text { Fuzzy supervision and application to lean } \\
\text { production }\end{array}$ & $\begin{array}{l}\text { International } \\
\text { Journal of Systems } \\
\text { Science }\end{array}$ \\
\hline Sycara et al. & 1991 & Distributed constrained heuristic search & $\begin{array}{l}\text { IEEE Transactions } \\
\text { on Systems, Man } \\
\text { and Cybernetics }\end{array}$ \\
\hline Benhabib et al. & 1989 & $\begin{array}{l}\text { Integrated manufacturing work cell } \\
\text { management system }\end{array}$ & $\begin{array}{l}\text { Manufacturing } \\
\text { review }\end{array}$ \\
\hline Bruce M. and Adam A. & 1989 & $\begin{array}{l}\text { Expert systems and women's lives: A } \\
\text { technology assessment }\end{array}$ & Futures \\
\hline Morris A. and Walton $\mathrm{K}$. & 1989 & $\begin{array}{l}\text { Shortage of expert system personnel in } \\
\text { the UK - hype or reality? }\end{array}$ & Expert Systems \\
\hline Diederich et al. & 1987 & $\begin{array}{c}\text { KRITON: a knowledge-acquisition tool for } \\
\text { expert systems }\end{array}$ & $\begin{array}{l}\text { International } \\
\text { Journal of Man- } \\
\text { Machine Studies }\end{array}$ \\
\hline Chisholm A. & 1987 & $\begin{array}{l}\text { The social effects of intelligent } \\
\text { manufacturing systems }\end{array}$ & $\begin{array}{l}\text { Robotics and } \\
\text { Computer } \\
\text { Integrated } \\
\text { Manufacturing }\end{array}$ \\
\hline Laurig W. & 1987 & $\begin{array}{l}\text { Do you believe in the advantage of } \\
\text { expert systems in industrial ergonomics? }\end{array}$ & $\begin{array}{l}\text { International } \\
\text { Journal of } \\
\text { Industrial } \\
\text { Ergonomics }\end{array}$ \\
\hline Nilsson N. & 1985 & $\begin{array}{l}\text { Artificial intelligence, employment, and } \\
\text { income }\end{array}$ & $\begin{array}{l}\text { Human Systems } \\
\text { Management }\end{array}$ \\
\hline Gurstein M. & 1985 & $\begin{array}{c}\text { Social impacts of selected artificial } \\
\text { intelligence applications. The Canadian } \\
\text { context }\end{array}$ & Futures \\
\hline Baráth E. and Futó I. & 1984 & $\begin{array}{l}\text { A regional planning system based on } \\
\text { artificial intelligence concepts }\end{array}$ & $\begin{array}{l}\text { Papers of the } \\
\text { Regional Science } \\
\text { Association }\end{array}$ \\
\hline Von Tomkewitsch R. & 1983 & $\begin{array}{l}\text { Fire detector systems with 'distributed } \\
\text { intelligence' the pulse polling system }\end{array}$ & Fire Safety Journal \\
\hline
\end{tabular}

